\title{
Biophysical Properties and Cytotoxicity of Feruloylated Helix Lucorum Hemocyanin
}

\author{
Maya Guncheva, ${ }^{1, *}$ Krassimira Idakieva, ${ }^{1}$ Svetla Todinova, ${ }^{2}$ Elena Stoyanova ${ }^{3}$ \\ and Denitsa Yancheva ${ }^{1}$ \\ ${ }^{1}$ Institute of Organic Chemistry with Centre of Phytochemistry, Bulgarian Academy of Sciences; Sofia 1113, Bulgaria; \\ ${ }^{2}$ Institute of Biophysics and Biomedical Engineering, Bulgarian Academy of Sciences, Sofia 1113, Bulgaria; \\ ${ }^{3}$ Institute of Biology and Immunology of Reproduction, Bulgarian Academy of Sciences, Sofia 1113, Bulgaria \\ *Corresponding author: E-mail: maiag@orgchm.bas.bg (M. Guncheva)
}

Received: 07-11-2019

\begin{abstract}
For the first time Helix lucorum hemocyanin $(\mathrm{HlH})$ has been feruloylated. Two $\mathrm{HlH}$ conjugates with 40- and 120-ferulic acid residues were prepared, denoted as FA-HlH-1 and FA-HlH-2. Expectedly, the feruloylation of $\mathrm{HlH}$ induced a rearrangement of the protein molecule, a decrease in the $\alpha$-helical structure at the expense of $\beta$-structures was observed. Besides, the FA-HlH conjugates were more prone to aggregation, which is probably due to the stabilization of the partially unfolded protein molecules by non-covalent bonding. Interestingly, the thermal stability of $\mathrm{HlH}$ was not affected by the modification. The native and feruloylated $\mathrm{HlH}$ were not toxic to normal fibroblasts (BJ cells). We observed a decrease in cell viability of breast cancer MCF-7 cells to about $66 \%$ after a $48 \mathrm{~h}$ exposure to $70 \mu \mathrm{g} /$ well of FA-HlH- 2 .
\end{abstract}

Keywords: Hemocyanin conjugates; ferulic acid; conformational stability; thermal stability; cytotoxicity

\section{Introduction}

Ferulic acid (FA) is a naturally occurring antioxidant, radical scavenging and photoprotective agent with huge therapeutic potential. It has been reported that FA has also strong hepatoprotective activity. ${ }^{1}$ Much attention has been paid in the literature on the beneficial role of FA in the treatment and prevention of Alzheimer's disease, a serious neurodegenerative disorder. ${ }^{2}$ In addition, FA inhibits melanin production, therefore can be involved in formulations for skin depigmentation. ${ }^{3}$ Interestingly, graft copolymers containing ferulic and hyaluronic acid exhibit wound healing properties and can be involved in medicines for the treatment of chronic and acute wounds. ${ }^{4} \mathrm{FA}$ is also considered to have potential as an anti-inflammatory drug for curing endometritis. It has been shown that FA reduces the level of the lipopolysaccharide-induced pro-inflammatory cytokines released by bovine endometrial epithelial cells if they are pretreated with the compound. ${ }^{5}$ On the other hand, chitosan-FA conjugates are proposed as novel drug delivery system based, ${ }^{6}$ while FA-modified glycol chitosan exhibited remarkable neuroprotective activity and can be applied in functional resto- ration of the traumatically injured spinal cord, a life-threatening trauma. ${ }^{7}$ Recently, Caia et al. have reported the preparation of functional foods based on FA grafted curdlans, water-insoluble linear beta-1,3-glucans. ${ }^{8}$ In addition, Liu et al. have shown that daily supplements of a sodium ferulate increased the relative abundance of Lactobacillus and Parabacteroides in mice model of transverse aortic construction and the changes in the gut microbiota resulted in an improved cardiac function in the tested animals. ${ }^{9}$

Here we report the preparation of two FA-hemocyanin conjugates. Hemocyanins $(\mathrm{Hc})$ are large complex respiratory proteins freely dissolved in the hemolymph of arthropods and mollusks.${ }^{10} \mathrm{Hc}$ isolated from Keyhole limpet (KLH) is commercialized and is applied as an immunotherapeutic in case of prostate cancer for several decades. ${ }^{11}$ Currently, many other vaccines against non-Hodgkins lymphoma, cutaneous melanoma, breast and bladder cancer, that are based on KLH undergo clinical trials. In addition, the whole protein or its subunits are used protein carriers or adjuvants. ${ }^{11}$ Many other Hcs have been isolated and structurally characterized, some exhibit anticancer, immunostimulatory, antiviral, antifungal activities in in vitro and in vivo assays. ${ }^{12,13,14}$ At present, 
KHL- $\beta$-1,2-mannan-peptide conjugates are tested as antifungal vaccines against $C$. albicans, $C$. tropicalis, $C$. lustani$a e$, and C. glabrata. ${ }^{\mathrm{f}}$ Based on KHL-conjugates are developed easy and fast ELISA methods for detection neurotoxins, vaccines against drugs of abuse and vaccines administrated by new routes. ${ }^{15,16,17} \mathrm{Hc}$ from Helix lucorum $(\mathrm{HlH})$ has been recently isolated and characterized. ${ }^{18}$ Lately, it has been reported that $\mathrm{HIH}$ and its structural subunits are cytotoxic to bladder carcinoma cells. ${ }^{19}$

The aim of the study is to prepare $\mathrm{FA}-\mathrm{HlH}$ conjugates and to assess the effect of the feruloylation on the $\mathrm{HlH}$ conformation and thermal stability. Cytotoxic effect of the FA-HlH conjugates against fibroblasts (BJ cells), hormone-dependent breast cancer cells (MCF-7 cells) and hormone-independent breast cancer cells (MDA-MB-231 cells). Experiments with the native $\mathrm{HlH}$ were conducted for comparison.

\section{Materials and Methods}

\section{1. Materials}

Ferulic acid (>99\%), N-(3-Dimethylaminopropyl)- $\mathrm{N}^{\prime}$-ethylcarbodiimide hydrochloride (>98\%) (EDC), $\mathrm{N}$ - hydroxysuccinimide (>98\%) (NHS), thiazolyl blue tetrazolium bromide (98\%, MTT), Dulbecco's Modified Eagle's (DMEM) low glucose medium, fetal bovine serum, $0.25 \%$ trypsin-EDTA solution and penicillin-streptomycin-amphotericin B antibiotic and disposable PD-10 columns were purchased from Sigma-Aldrich.

$\mathrm{Hc}$ was isolated from the hemolymph of Helix lucorum garden snails as described in. ${ }^{10}$ All other used organic solvents and salts were analytical grade.

The human breast carcinoma cell lines (MCF-7 and MDA-MB-231) and normal human skin fibroblasts (BJ cell line) were obtained from the American Type Culture Collection (ATCC).

\section{2. Preparation of the FA-HlH Conjugates}

At first, FA was stirred with EDC/NHS in $50 \mathrm{mM}$ phosphate saline buffer (PBS)(pH 7.2) at a stoichiometric molar ratio of FA/EDC/NHS $=1: 2: 2$ for $2 \mathrm{~h}$ at room temperature. Then, a 100-to 500 -fold molar excess of the obtained NHS-ester of FA was added to the native $\mathrm{HlH}$ dissolved in PBS. The mixture was stirred at room temperature for $4 \mathrm{~h}$, and then incubated at $4{ }^{\circ} \mathrm{C}$ overnight. The FA-HlH conjugates were purified on prepacked PD-10 desalting columns following the manufacturer's instructions.

The concentration of the native and feruloylated $\mathrm{HlH}$ was determined using the Bradford assay. ${ }^{20}$

Absorbance spectra of the protein samples were recorded on Evolution ${ }^{\mathrm{TM}} 300$ UV-Vis Spectrophotometer (Thermo Electron Corporation) equipped with a Peltier temperature control accessory with the highest resolution $(1 \mathrm{~nm})$. The degree of feruloylation was estimated using the differences in the spectra of the native and the feruloylated $\mathrm{HlH}$ at $315 \mathrm{~nm}$. The molar extinction coefficient of ferulic acid at $315 \mathrm{~nm}$ in PBS (pH 7.2, $50 \mathrm{mM}$ ) is 13740 L. $\mathrm{mol}^{-1} \cdot \mathrm{cm}^{-1}$.

\section{3. Fourier-Transform Infrared Spectroscopy (FTIR)}

FTIR spectra were recorded on Bruker Vertex 70 spectrometer equipped with a diamond ATR accessory in the frequency region $4000-600 \mathrm{~cm}^{-1}$ with 128 scannings at a resolution of $1 \mathrm{~cm}^{-1}$. Protein samples were dissolved in PBS buffer ( $\mathrm{pH} 7.2,50 \mathrm{mM}$ ) at a concentration of $20 \mathrm{mg} /$ $\mathrm{mL}$. All spectra were obtained after subtraction of the buffer baseline and were strictly collected under the same conditions, after adjusting the subtraction baseline until a flat baseline was obtained in the $2000-1700 \mathrm{~cm}^{-1}$ region. Second derivatives were obtained using the Savitzky-Golay algorithm based on 25 smoothing points. Curve fitting of the amide I band from 1700 to $1600 \mathrm{~cm}^{-1}$, in water, was performed using Opus software version 5.5 according to the Local Least Squares algorithm. The initial bandwidth of all components was set to $12 \mathrm{~cm}^{-1}$ and the components were approximated by mixed Lorentzian/Gaussian functions. Amide I band positions are assigned to the corresponding secondary structures according to the literature. ${ }^{21}$

\section{4. Differential Scanning Calorimetry (DSC)}

DSC scans were carried out on a high-sensitivity differential scanning microcalorimeter DASM-4 (Biopribor, Pushchino, Russia), with a sensitivity $>0.017 \mathrm{~mJ} \mathrm{~K}-1$ and a noise level $< \pm 0.05 \mu \mathrm{W}$. The protein samples were dissolved in PBS (pH 7.2, $50 \mathrm{mM}$ ) at a concentration of $3 \mathrm{mg} / \mathrm{mL}$. Heat capacity versus temperature profiles were obtained in the range $30-110{ }^{\circ} \mathrm{C}$ at scan rate $1 \mathrm{~K} \cdot \mathrm{min}^{-1}$. Sample scans were buffer-subtracted, concentration normalized and corrected with the progress baseline. DSC curves were analyzed using the ORIGIN (MicroCal Software) program. Experimental deconvolution of heat capacity curves into individual components by a successive annealing procedure was applied following the approach of Idakieva et al. ${ }^{22}$

\section{5. Cell Culture}

BJ, MCF-7, and MDA-MB-231 cells were maintained in a complete growth DMEM low glucose medium supplemented with $10 \%(\mathrm{v} / \mathrm{v})$ fetal bovine serum and penicillin-streptomycin-amphotericin $\mathrm{B}$ antibiotic mixture under a humidified atmosphere of $5 \% \mathrm{CO}_{2}$ at $37^{\circ} \mathrm{C}$. The medium was changed every other day.

\section{6. Cell Viability Assay}

Methylthiazolyldiphenyl-tetrazolium bromide (MTT) assays were carried out to evaluate the cytotoxic 
effect of FA-HlH on BJ, MCF-7, and MDA-MB-231 cells. ${ }^{23}$ The cells were seeded in 96-well plate at a density of $1 \times 10^{4}$ cells per well and cultured in complete growth medium for $24 \mathrm{~h}$. Then, cells were incubated with $0-70 \mu \mathrm{g} /$ well of native or FA-modified $\mathrm{HlH}$ for $24 \mathrm{~h}$ and $48 \mathrm{~h}$. The culture medium was changed to $100 \mu \mathrm{L}$ serum-free medium containing $500 \mu \mathrm{g} / \mathrm{mL}$ MTT and plates were incubated for $3 \mathrm{~h}$ at $37^{\circ} \mathrm{C}$ and $5 \% \mathrm{CO}_{2}$. The formazan salts were dissolved in $120 \mu \mathrm{L}$ of dimethylsulfoxide (DMSO) and the absorbance was measured at $544 \mathrm{~nm}$ on FLUOstar Optima microplate reader (BMG Labtech, Germany). Samples containing only DMSO were used as a blank control. Control experiments containing untreated with $\mathrm{FA}-\mathrm{HlH}$ or $\mathrm{HlH}$ cells were carried out. The survival of the cells, treated with $\mathrm{HIHs}$ was presented in percentages from the corresponding control. Two independent experiments were performed for each cell line.

\section{7. Statistical Analysis}

Data were analyzed by one-way ANOVA followed by Tukey-Kramer post-hoc test. The values were considered to be significantly different if the $\mathrm{p}$-value was $<0.05$.

\section{Results and Discussion}

\section{1. Synthesis and Biophysical Characterization of the FA-HIH Conjugates}

Ferulic acid was covalently linked to the accessible $\varepsilon$-amino groups of lysine residues and $\mathrm{N}$-terminal amino groups of $\mathrm{HlH}$ via activated ester method (Scheme 1).
The reaction was conducted under mild reaction conditions in PBS buffer ( $\mathrm{pH}$ 7.2), at which the primary amino groups are positively charged and exposed to the protein surface. The intermediate, NHS ester of ferulic acid was not isolated and synthesis was performed in one step. An excess of ferulic acid (100- to 500- fold) was used in order to obtain conjugates with a high degree of substitution. Two FA-HlH conjugates containing 40- and 120 ferulic acid residues were prepared and isolated, and were denoted as FA-HlH-1 and $\mathrm{FA}-\mathrm{HlH}$, respectively.

We applied ATR-FTIR spectroscopy to assess the effect of the modification on the $\mathrm{HlH}$ secondary structure. Spectra of FA-HlH-1, FA-HlH-2, and native $\mathrm{HlH}$ were compared in the Amide I band region (1700-1600 $\left.\mathrm{cm}^{-1}\right)$, which is mainly due to $\mathrm{C}=\mathrm{O}$ stretching vibrations (70$80 \%$ ) of the amide groups and is known as conformationally sensitive. ${ }^{21}$ For the three protein samples, the original, the second derivative and the deconvoluted spectra scaled to an identical area under Amide I and Amide II (1700$1400 \mathrm{~cm}^{-1}$ ) are given in the Supplementary (Fig. S1). The spectra were analyzed using 7 (native $\mathrm{HlH}$ and $\mathrm{FA}-\mathrm{HlH}-1$ ) or 8 (FA-HlH-2) bands having a centre within 1600-1615; 1615-1640; 1640-1660; 1660-1690; and 1690-1700 $\mathrm{cm}^{-1}$, which are assigned to extended conformations or sidechains residues, $\beta$-sheets; $\alpha$-helical, coiled or disordered structures; $\beta$-turns and antiparallel $\beta$-sheet structures. ${ }^{21}$ As obtained from the FTIR studies, the conformation of the native and the two feruloylated $\mathrm{HlHs}$ are reported in Table 1.

We observed a decrease in the $\alpha$-helices at expense of the $\beta$-structures, which is an indication that $\mathrm{HlH}$ is partially unfolded due to the feruloylation. In the spectra of FA$\mathrm{HlH}-1$ and FA-HlH-2 are found the typical bands that are assigned to protein aggregates, which are probably addi-

a)

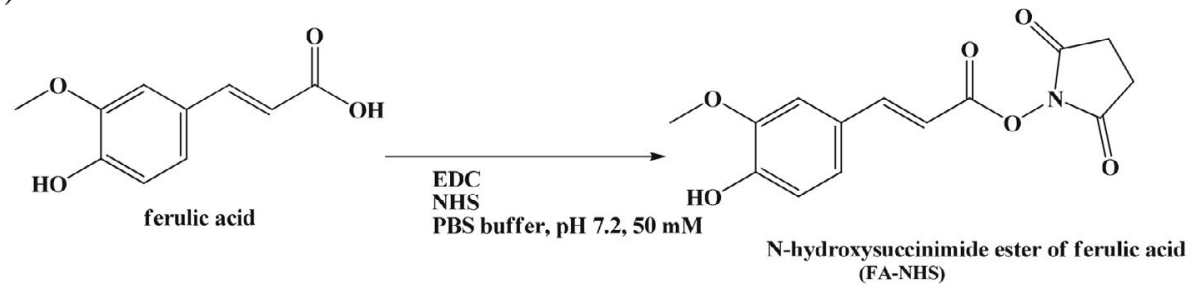

b)

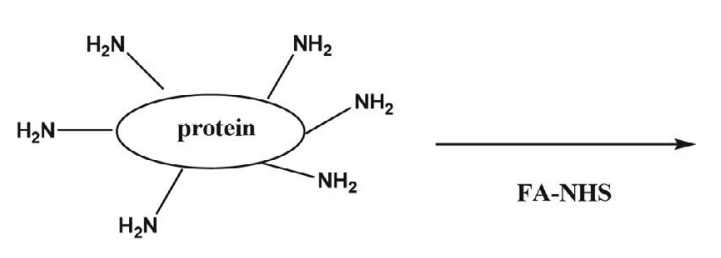

Helix lucorum hemocyanin $(\mathrm{HIH})$

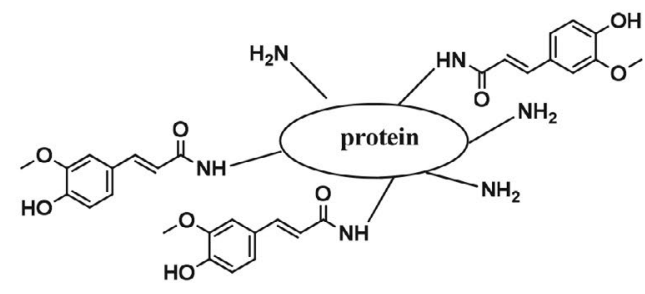

FA-HIH

Scheme 1: Steps in chemical modification of Helix lucorum hemocyanin with ferulic acid: a) activation of the carboxylic group of ferulic acid; b) Conjugation of ferulic acid and primary amino groups of the hemocyanin. 
Table 1. Secondary structure band assignments for the native and ferulic acid-conjugated Helix lucorum hemocyanin in $50 \mathrm{mM}$ PBS buffer (pH 7.2).

\begin{tabular}{|c|c|c|c|c|c|c|}
\hline \multirow{2}{*}{$\begin{array}{l}\text { Assignment of the } \\
\text { secondary structure } \\
\text { components }^{21}\end{array}$} & \multicolumn{2}{|c|}{ HlH native } & \multicolumn{2}{|c|}{ FA-HIH-1 } & \multicolumn{2}{|c|}{ FA-HIH-2 } \\
\hline & $\begin{array}{l}\text { Band position } \\
\quad\left(\mathrm{cm}^{-1}\right)\end{array}$ & $\begin{array}{l}\text { Relative } \\
\text { area (\%) }\end{array}$ & $\begin{array}{l}\text { Band position } \\
\qquad\left(\mathrm{cm}^{-1}\right)\end{array}$ & $\begin{array}{l}\text { Relative } \\
\text { area (\%) }\end{array}$ & $\begin{array}{l}\text { Band position } \\
\left(\mathrm{cm}^{-1}\right)\end{array}$ & $\begin{array}{c}\text { Relative } \\
\text { area (\%) }\end{array}$ \\
\hline \multirow[t]{2}{*}{ anti-parallel $\beta$-sheets } & - & - & 1609 & 11.31 & 1613 & 10.91 \\
\hline & & & & & 1694 & 2.12 \\
\hline \multirow[t]{5}{*}{$\beta$-structures (sheets and turns) } & 1629 & 0.15 & 1621 & 7.31 & 1624 & 10.28 \\
\hline & 1633; & 8.0 & 1633 & 14.0 & 1632 & 14.57 \\
\hline & 1664 & 11.76; & 1667 & 12.74 & 1666 & 15.80 \\
\hline & 1676 & 23.31; & 1683 & 10.73 & 1682 & 7.74 \\
\hline & 1690 & 7.90 & & & & \\
\hline a-helices & 1653 & 30.39 & 1651 & 20.79 & 1653 & 23.7 \\
\hline unordered structures/random coils & 1642 & 18.4 & 1644 & 23.13 & 1642 & 14.57 \\
\hline
\end{tabular}

FA-HlH-1 (40 ferulic acid residues); FA-HlH-2 (120 ferulic acid residues)

tionally stabilized by non-covalent interactions involving the aroma ring of the substituents.

Interestingly, despite of the observed conformational changes of the $\mathrm{HlH}$ induced by the modification, the thermal stability of the protein remained mostly unaffected. The DSC profiles of the native $\mathrm{HlH}, \mathrm{FA}-\mathrm{HlH}-1$, and FA$\mathrm{HlH}-2$ are depicted in Fig. 1.

The experiment was conducted at a protein concentration of $3 \mathrm{mg} / \mathrm{mL}$ in PBS ( $\mathrm{pH} 7.2,50 \mathrm{mM}$ ), and heating rate $-1 \mathrm{~K} / \mathrm{min}$.

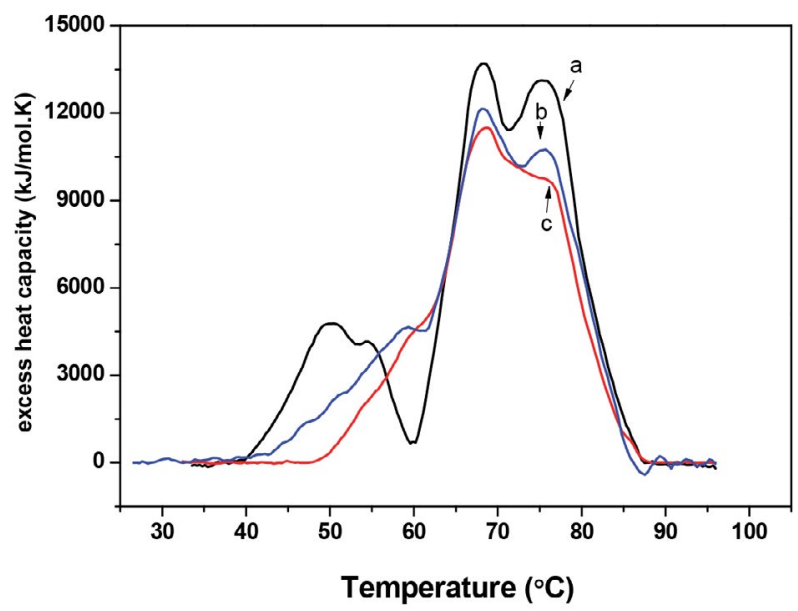

Fig. 1. DSC profiles of the thermal unfolding of native $\mathrm{HlH}$ (a) and conjugated with 40 and 120 -ferulic acid residues, FA-HlH-1 (b) and FA-HlH-2 (c).
As seen the three DSC curves have an asymmetric shape, which is due to the complex multimeric structure of hemocyanins and is in agreement with the literature data on the thermal denaturation of another $\mathrm{Hc}$ in a phosphate-saline buffer. ${ }^{16}$ The thermal denaturation temperatures of the feruloylated $\mathrm{HlH}$ are slightly shifted toward the higher temperatures (by up to $5^{\circ} \mathrm{C}$ ) in comparison to denaturation temperatures of the native $\mathrm{HlH}$. DSC curves were experimentally deconvoluted using a successive annealing procedure as previously described by Idakieva et $\mathrm{al},{ }^{24}$ which allowed a more precise estimation of the thermodynamic parameters, transition temperature $\left(\mathrm{Tm}_{\mathrm{i}}\right)$ and calorimetric enthalpy $\left(\Delta \mathrm{H}_{\mathrm{i}}\right)$ (Table 2). Apparently, the thermal stability of $\mathrm{HlH}$ was preserved after the modification.

\section{2. Comparison of the Cytotoxicity of the Native and the Feruloylated $\mathrm{HlH}$}

The effect of FA-HlH-1 and FA-HlH-2 on the cell viability of human fibroblasts (BJ cells) was tested in a concentration range between 25 and $200 \mu \mathrm{g} /$ well (Fig 2).

We observed a slight increase in proliferation or no effect after a $24 \mathrm{~h}$ exposure of the BJ cells to 25 or $50 \mu \mathrm{g} / \mathrm{mL}$ of the native or feruloylated $\mathrm{HlH}$. For the same samples, not evidence of any sign of toxicity was observed even after longer incubation time. Reduction in BJ cell growth was observed after a $24 \mathrm{~h}$-treatment with $200 \mu \mathrm{g} /$ well $(18.4 \pm$ $5 \%, \mathrm{P}<0.001)$ of $\mathrm{FA}-\mathrm{HlH}-1$, a similar effect was produced

Table 2. The thermodynamic parameters of the native and ferulic acid-modified $\mathrm{HlH}$ thermal denaturation.

\begin{tabular}{|c|c|c|c|c|c|c|c|c|c|c|c|c|}
\hline Sample & $\begin{array}{l}\mathrm{T}_{\mathrm{m} 1} \\
\left({ }^{\circ} \mathrm{C}\right)\end{array}$ & $\begin{array}{c}\Delta \mathrm{H}_{1} \\
\left(\mathrm{~kJ} \mathrm{~mol}^{-1}\right)\end{array}$ & $\begin{array}{l}\mathrm{T}_{\mathrm{m} 2} \\
\left({ }^{\circ} \mathrm{C}\right)\end{array}$ & $\begin{array}{c}\Delta \mathrm{H}_{2} \\
\left(\mathrm{~kJ} \mathrm{~mol}^{-1}\right)\end{array}$ & $\begin{array}{l}\mathrm{T}_{\mathrm{m} 3} \\
\left({ }^{\circ} \mathrm{C}\right)\end{array}$ & 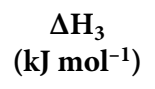 & $\begin{array}{l}\mathrm{T}_{\mathrm{m} 4} \\
\left({ }^{\circ} \mathrm{C}\right)\end{array}$ & $\begin{array}{c}\Delta \mathrm{H}_{4} \\
\left(\mathrm{~kJ} \mathrm{~mol}^{-1}\right)\end{array}$ & $\begin{array}{l}\mathrm{T}_{\mathrm{m} 5} \\
\left({ }^{\circ} \mathbf{C}\right)\end{array}$ & $\begin{array}{c}\Delta \mathrm{H}_{5} \\
\left(\mathrm{~kJ} \mathrm{~mol}^{-1}\right)\end{array}$ & $\begin{array}{c}\Delta \mathrm{H}_{\text {total }} \\
\left(\mathrm{kJ} \mathrm{mol}^{-1}\right)\end{array}$ & 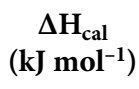 \\
\hline native $\mathrm{HlH}$ & 49.9 & 38080 & 55.2 & 10752 & 67.6 & 92858 & 75.7 & 99308 & 79.8 & 22263 & 263261 & 279337 \\
\hline FA-HlH-1 & & & 60.4 & 40802 & 68.3 & 79585 & 75.4 & 77372 & 80.4 & 20111 & 217870 & 214977 \\
\hline FA-HlH-2 & & & 58.9 & 72399 & 68.5 & 70882 & 75.5 & 67464 & 81.0 & 27466 & 239091 & 245351 \\
\hline
\end{tabular}

FA-HlH-1 (40 ferulic acid residues); FA-HlH-2 (120 ferulic acid residues) 

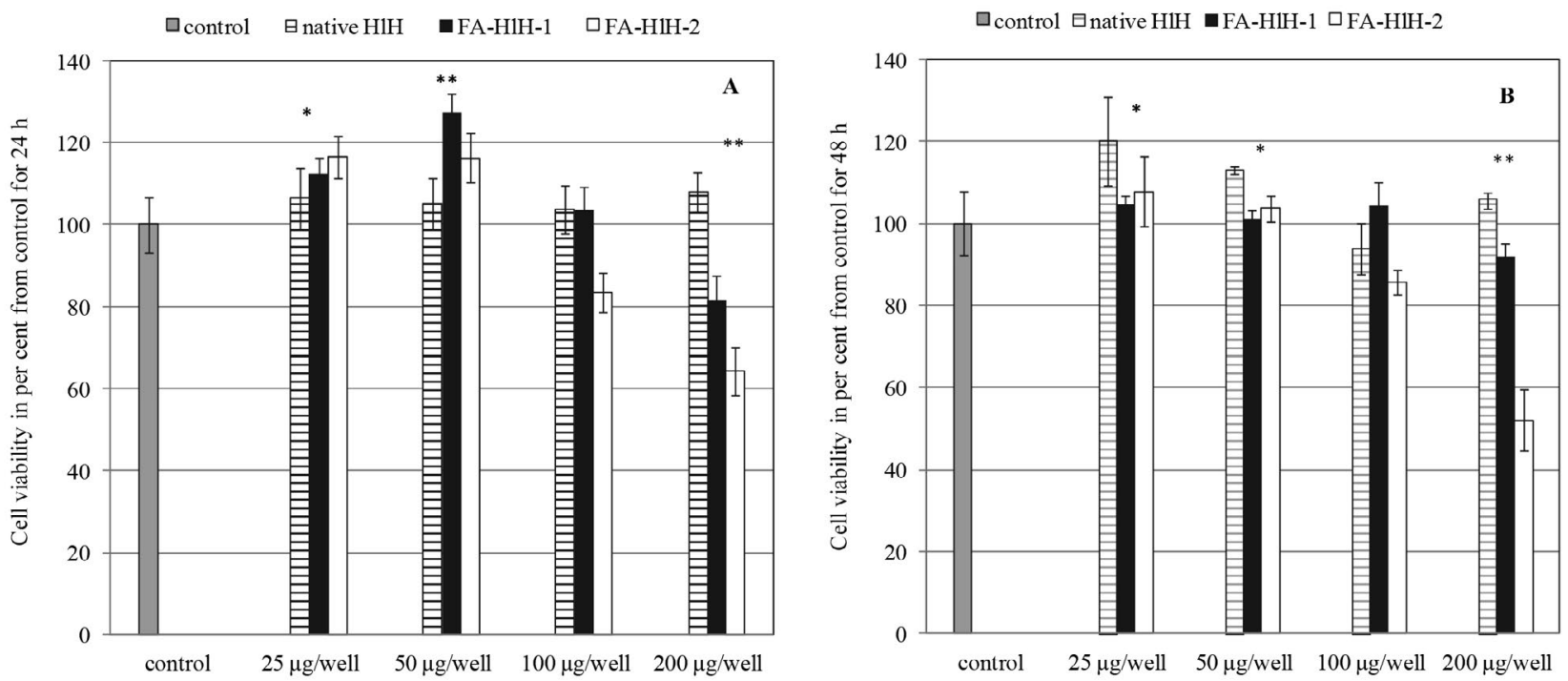

Fig. 2. Antiproliferative effect of native and ferulic acid conjugated $\mathrm{HlH}$ on normal fibroblasts (BJ cells) after $24 \mathrm{~h}(\mathrm{~A})$ and $48 \mathrm{~h}$ (B) incubation. Data are presented as mean $\pm \mathrm{SD},{ }^{*}(\mathrm{p}<0.05),{ }^{* *}(\mathrm{p}<0.01), \mathrm{n}=3$.

by $100 \mu \mathrm{g} /$ well of FA-HlH-2. The lowest cell viability of the BJ cells, 64.1 and $51.1 \%$, was detected after 24 and $48 \mathrm{~h}$, respectively of incubation with $200 \mu \mathrm{g} / \mathrm{mL}$ FA-HlH-2.

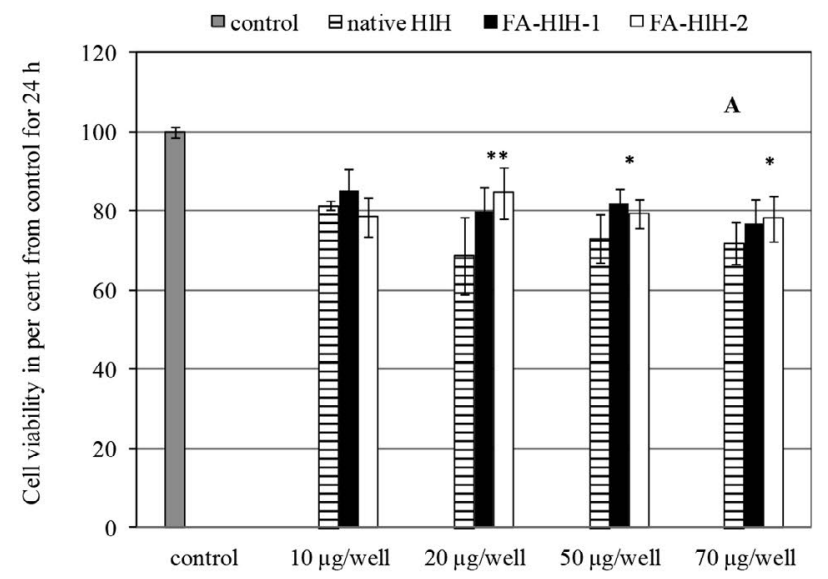

Cytotoxicity of the feruloylated $\mathrm{HlH}$ against two breast cancer cell lines, a hormone-dependent (MCF-7) and a hormone-independent (MDA-MB-231), was esti-

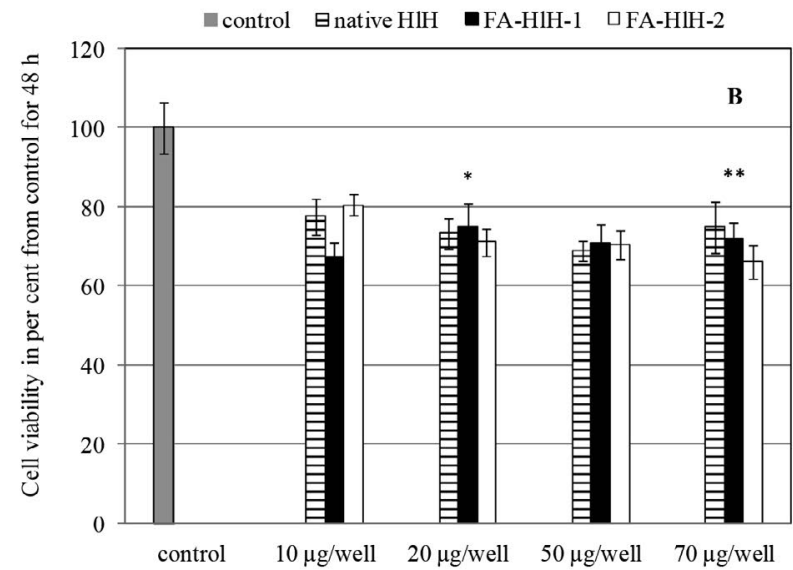

Fig. 3. Effect of native $\mathrm{HlH}$ and ferulic acid conjugated $\mathrm{HlH}$ on MCF-7 cell viability after $24 \mathrm{~h}$ (A) and $48 \mathrm{~h}$ (B) incubation. Data are presented as mean $\pm \mathrm{SD},{ }^{*}(\mathrm{p}<0.05),{ }^{* *}(\mathrm{p}<0.01), \mathrm{n}=3$.
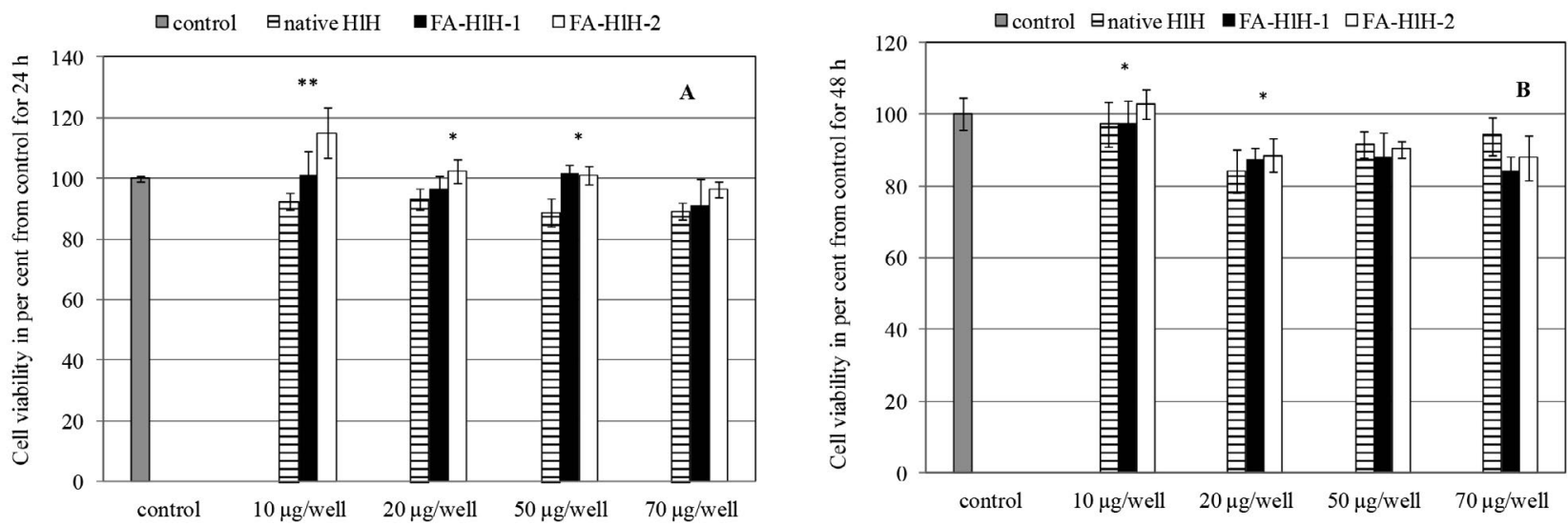

Fig. 4. Effect of native $\mathrm{HIH}$ and ferulic acid conjugated $\mathrm{HlH}$ on MDA-MB-231 cell viability after $24 \mathrm{~h}(\mathrm{~A})$ and $48 \mathrm{~h}$ (B) incubation. Data are presented as mean $\pm \mathrm{SD},{ }^{*}(\mathrm{p}<0.05),{ }^{* *}(\mathrm{p}<0.01), \mathrm{n}=3$. 
mated at concentrations from 10 to $70 \mu \mathrm{g} /$ well, which are not toxic for normal fibroblasts. The native and the two feruloylated $\mathrm{HlHs}$ produce a similar effect within ond the same cell line. The effect was more pronounced for FA$\mathrm{HlH}-2$, especially for the MCF-7 cells, for which we noticed concentration dependence (Fig. 3). The three Hcs had negligible cytotoxic effects on MDA-MB-231 cells, even at a concentration of $70 \mu \mathrm{g} / \mathrm{well}$, the highest tested concentration (Fig. 4).

\section{Conclusions}

For the first time, two conjugates of Helix lucorum hemocyanins with ferulic acid have been successfully prepared. The modified Hcs is likely to adopt more extended $\beta$ conformations and are apparently additionally stabilized by $\pi-\pi$ stacking interactions that involve the ferulic acid residues and aromatic amino acid residues of the protein, which on the other hand explains their increased thermal stability in comparison to that of the native protein. At a concentration of $50 \mu \mathrm{g} /$ well, FA-HlH-1, the sample containing 40 ferulic acid residues, appears to stimulate the growth of the fibroblasts. The moderate to excellent activity and selectivity of the native and the feruloylated $\mathrm{HlH}$ towards MCF-7 cells makes them promising for future studies because of their biopharmaceutical potential.

\section{Supplementary Materials}

The supplementary PDF file contains the original; second derivative and deconvoluted in the Amide I band region FTIR spectra of the native and the two feruloylated (FA-HlH-1 and FA-HlH-2) hemocyanins. A graphic illustration of the experimental annealing procedure for the DSC experiment is also given.

\section{Acknowledgement}

The financial support of the Bulgarian National Science Fund (Project: ДКОСТ 01/27) is gratefully acknowledged.

\section{References}

1. R. Rukkumani, K. Aruna, P. S. Varma, V. P. Menon, J. Med. Food. 2004, 7, 456-461. DOI:10.1089/jmf.2004.7.456

2. S.F. Nabavi, K. P. Devi, D.S. Malar, A. Sureda, M. Daglia, S.M. Nabavi, Mini-Rev. Med. Chem. 2015, 15, 776-788.

DOI:10.2174/1389557515666150522102545

3. H. Maruyama, F. Kawakami, T. T. Lwin, M. Imai, F. Shamsa, Biol. Pharm. Bull. 2018, 41, 806-810.

DOI:10.1248/bpb.b17-00892
4. G. Valacchi, G. Grisci, C. Sticozzi, Y. Lim, M. Paolino, G. Giuliani, R. Mendichi,. G. Belmonte, R. Artusi, A. Zanardi, P. Garofalo, G. Giorgi, A. Cappelli, L. Rovati, J. Mat. Chem. B. 2015, 3, 7037-7045. DOI:10.1039/C5TB00661A

5. P. Yin, Z. Zhang, J. Li, Y.Shi, N. Jin, W. Zou, Q. Gao, W. Wang, F. Liu, Res. Vet. Sci. 2019, 126, 164-169.

DOI:10.1016/j.rvsc.2019.08.018

6. C. Li, J.-B. Li, Int. J. Biol. Macromol. 2017, 105, 1539-1543. DOI:10.1016/j.ijbiomac.2017.04.103

7. W. Wu, S.-Y. Lee, X. Wu, J. Y. Tyler, H. Wang, Z. Ouyang, K. Park, X.M. Xu, J.X. Cheng, Biomaterials 2014, 35, 2355-2364. DOI:10.1016/j.biomaterials.2013.11.074

8. W.-D. Caia, J. Zhu, L.-X. Wu, Z.-R. Qiao, L. Li, J.-K. Yan, Food Chem.2019, 300, 125221.

DOI:10.1016/j.foodchem.2019.125221

9. Z. Liu, Z. Ma, H. Zhang, B. Seel, S. Haiyue, L. D. An, Q. Zhan, W. Lai, Q. Zeng, H. Rend, D. Xu, Biomed. Pharmacother. 2019, 120, 109482. DOI:10.1016/j.biopha.2019.109482

10. C. Gatsogiannis, O. Hofnagel, J. Markl, Stefan Raunser, Structure 2015, 23, 93-103. DOI:10.1016/j.str.2014.10.013

11. J. R. Harris, J. Markl, Micron 1999, 30, 597-623. DOI:10.1016/S0968-4328(99)00036-0

12. C. J. Coates, J. Nairn, Dev. Comp. Immunol. 2014, 45, 43-55. DOI:10.1016/j.dci.2014.01.021

13. H. K. Kang, H. Ho Lee, C. H. Seo, Y. Park, Mar. Drugs 2014, 17,350 .

14. A. Dolashki, L. Velkova, W. Voelter, P. Dolashka, Z. Naturforsch. C 2019, 74, 113-123. DOI:10.1515/znc-2018-0084

15. S. Sato, S. Takaishi, K.Yasumoto, S. Watabe, Toxins 2019, 11, 551. DOI: $10.3390 /$ toxins 11100551

16. F. Baruffaldi, M. D. Raleigh, S. J. King, M. J. Roslawski, A. K. Birnbaum, C. Hassler, F. I. Carroll, S. P. Runyon, S. Winston, P. R. Pentel, M. Pravetoni, Mol. Pharmaceutics, 2019, 16, 2364-2375. DOI:10.1021/acs.molpharmaceut.8b01296

17. Z. Oreskovic, K. Nechvatalova, J. Krejci, V. Kummer, M. Faldyna, PloSOne, 2019, 14, e0211896.

DOI:10.1371/journal.pone.0211896

18. L. Velkova, I. Dimitrov, H. Schwarz, S. Stevanovic, W. Voelter, B. Salvato, P. Dolashka-Angelova, Comp. Biochem. Physiol. B Biochem. Mol. Biol. 2010, 157, 16-25.

DOI:10.1016/j.cbpb.2010.04.012

19. A. Dolashki, P. Dolashka, A. Stenzl, S. Stevanovic, W. K. Aicher, L. Velkova, R. Velikova, W. Voelter, Biotechnol. Biotechnol. Equip. 2019, 33, 20-32. DOI:10.1080/13102818.2018.1507755

20. M. Bradford, Anal. Biochem. 1976, 72, 248-254. DOI:10.1006/abio.1976.9999

21. A. Barth, Biochim. Biophys. Acta. 2007, 1767, 1073-1101. DOI:10.1016/j.bbabio.2007.06.004

22. K. Idakieva, C. Gielens, N. Siddiqui, L. Doumanova, B. Vasseva, Kostov, V.L. Shnyrov, Z. Naturfors. B. 2007, 62a, 499-506. DOI:10.1515/zna-2007-0906

23. T. Mosmann, J. Immunol. Meth. 1983, 65, 55-63. DOI:10.1016/0022-1759(83)90303-4

24. K. Idakieva, K. Parvanova, S. Todinova, Biochim. Biophys. Acta. 2005, 1748, 50- 56. DOI:10.1016/j.bbapap.2004.12.004 


\section{Povzetek}

Ferulacija hemocianina (HIH) Helix lucorum je opisana prvič. Pripravili smo dva HIH konjugata z 40-in 120-ostanki ferulične kisline, označena kot FA-hlh-1 in FA-hlh-2. Po pričakovanjih je ferulacija HlH povzročila preureditev beljakovinske molekule, opaženo je tudi zmanjšanje $\alpha$-spiralne strukture na račun $\beta$-struktur. Poleg tega so bili konjugati FA-HlH bolj nagnjeni k agregaciji, ki je verjetno posledica stabilizacije delno neprepognjenih beljakovinskih molekul z ne-kovalentnimi povezavami. Zanimivo je, da spremembe niso vplivale na toplotno stabilnost HlH. Nativne in ferulirane $\mathrm{HlH}$ niso strupene za normalne fibroblaste (celice BJ). Opazili smo zmanjšanje preživetja celic raka dojk MCF-7 na približno $66 \%$ po $48 \mathrm{~h}$ izpostavljenosti $70 \mu \mathrm{g} /$ žepek FA-HlH-2. 